\title{
Factors That Affect Liquidity of Commercial Banks in Kosovo
}

\author{
By Donjeta Morina ${ }^{1}$, Albert Qarri ${ }^{2}$
}

\begin{abstract}
A very important factor that affects the growth and survival of commercial banks is also the level of liquidity. Banking industry regulators require banks to possess liquid assets in order to fulfill their obligations to depositors and third parties accurately. Lack of liquidity reduces the ability of banks to meet their obligations and otherwise excess liquidity may be the cause of reduced profits for banks. There are many factors that can affect the position of liquidity in commercial banks and which factors cause unbalanced liquidity and as such also affect their performance. As a result, the study of these factors is of particular importance. The main objective of this study is to analyze the liquidity empathy of the banking sector to several specific banking and macroeconomic factors. To achieve this objective, the study uses regression analysis per a data set that includes a time of 8 years respectively the years 2012 - 2019. To build the necessary econometric model and to achieve the purpose of the study, data are taken from the publications of the Central Bank and the World Bank (GDP data), which data are analyzed for each quarter for the study period. After analyzing the available data, the study concludes that between the main factors that can affect the liquidity position of commercial banks, Non-performing loans, Capital adequacy, and Credit interest rate have the grand and most important impact on the liquidity banking position.
\end{abstract}

Keywords: Commercial banks, Liquidity, internal factors, external factors.

\section{Introduction}

Liquidity is explained as the bank's ability to fulfill its obligations on time without incurring any unexpected losses. According to Shershneva et.al., (2020), the basic scientific concept of liquidity in the bank is the ability to ensure timely and complete performance of obligations to depositors, creditors and other parties.

A commercial bank is considered liquid if it has sufficient funds to meet its obligations. Banks' liquidity problems are one of the main problems of their financial management. Lack of liquidity reduces the ability of banks to meet their obligations and otherwise excess liquidity may be the cause of reduced profits for banks.

There are many factors that can affect the liquidity position of banks, and which factors often disrupt the financial performance of banks causing unbalanced liquidity. These factors can be internal and external. Internal factors are those that are under the management of the bank and as such may be the benefits they realize, the quality of assets, the bank's capital, its size, etc. While external factors are those factors which are considered to be outside the responsibility of the bank managers and such factors are considered: economic growth, exchange rate, inflation and interest rates. All these factors have an 
important impact on the bank's liquidity and an imbalance of liquidity within banks can be presented as a significant problem of their financial health.

Kosovo's banking sector has continued to maintain a high level of stability over the years, which is characterized by a high degree of capitalization and a satisfactory liquidity position. The most important indicators for assessing the liquidity of the banking sector were considered to be the loan / deposit ratio and the ratio of liquid assets to short-term liabilities. During different periods, the banking system in Kosovo has been characterized by satisfactory values of these indicators, which shows the ability of the system to cope with liquidity risk.

The main objective of the study is to analyze the dependence of banks' liquidity in Kosovo, by certain factors (liquidity factors) based on regression analysis, using specific data on banks and macroeconomic variables for the period $2012-2019$.

\section{Literature Review}

Nowadays the activity of banks has expanded significantly and their traditional role is no longer important. Today they offer different products and services and as a result of increasing competition the efficiency of these products and services is constantly growing. Given their important role, it is imperative to study their liquidity as an important factor for financial success and stability as a whole.

Most banks hold a portion of assets that can be easily sold to meet liquidity needs, such as cash, bank deposits, and marketable securities. According to Devinaga (2010), regulators in the banking industry require banks to hold liquid assets (money) to deal with day-to-day activities such as meeting customer needs. He explained that this is possible if banks are able to raise enough money and this means that a bank's ability to survive depends heavily on its level of liquidity.

Theoretically, the factors that affect the liquidity of banks can be internal and external. Internal factors are those factors which are related with internal efficiency and managerial decisions and as such are considered to be the profitability of banks, capital adequacy, bank size, asset quality and lending growth. While external or macroeconomic factors are variables that are not under the control of the bank but reflect the legal and economic environment in which banks operate. Such factors that may affect the liquidity of these institutions are inflation rate, economic growth, interest rate and exchange rate.

There are a large number of studies that expound the liquidity of the banking sector and the factors which determine the banks' liquidity.

$\mathrm{Al}$ - Hamidi et. al. (2019) conducts a study on the liquidity of commercial banks in India. The study included 37 commercial banks for the period 2008-2017. According to these authors, Bank size (BS), Capital Adequacy Ratio (CAR), Return on Assets (ROA), had a positive and important impact on banks' liquidity, while Return in Equity (ROE) Asset Quality (CA) and Net Interest Margin (NIM) had a negative impact on banks' liquidity. While from macroeconomic factors, GDP and Interest rate had a significant negative impact whilst Inflation and Exchange rate had a positive impact on the liquidity of commercial banks in India.

Another study was conducted by Shah et. al. (2018) in the banking sector in Pakistan, a study that covers the period 2007 - 2016. This study included 23 commercial banks. 
According to them, Capital Adequacy (CAR) and Bank Size (BS) had a positive and important impact on the liquidity of commercial banks. While other factors such as ROA and GDP did not turn out to be significant in this case.

Feng (2017) studied the factors that have an impact on the liquidity of commercial banks in China and according to him the Non-performing loans ratio and the Capital Adequacy ratio are among the main factors that touch the liquidity of commercial banks. According to him, the ratio of NPLs is negatively related to the liquidity of banks. When the ratio of NPLs increases, banks' liquidity will decrease. Due to the increase in non-performing loans, commercial banks are not willing to take on greater credit risk, so they reduce lending and the decrease in loans leads directly to the decrease in the liquidity ratio. According to Feng (2017), even the capital adequacy ratio is negatively related to the banks liquidity.

Another study was conducted on Nepalese banks by Ojhi (2018). According to him, Return on assets and NPL (Non-performing loans) had a negative impact on banks' liquidity, while the ratio of Capital Adequacy, GDP and Inflation were positively related to the banks' liquidity. Positive correlation of GDP and inflation with banks' liquidity has also given the study conducted in Malaysia by Chong et. al. (2013). According to this, economic growth increases the ability of banks to finance additional assets and meet their liabilities at a lower cost, and the economic downturn yields the opposite effect.

\section{Methodology}

The paper is based entirely on secondary data, through which a quantitative analysis will be performed to see the sensitivity of banking liquidity from several factors that are considered most important for the study.

\subsection{Data collection}

Data to realize the empirical part of the study were collected for a period of 10 years, respectively for the period 2010 - 2019 and were analyzed for each quarter. These data are extracted from annual reports published by the Central Bank of Kosovo, with the exception of GDP data, which are extracted from the World Bank database, which provides public access to a large number of macroeconomic variables.

To achieve the purpose of the paper, data processing passed through several stages. First, the definition of the study variables was done, these variables were then coded and analyzed in the statistical software SPSS 23. 6 variables have been defined for the study, one dependent variable and 5 independent variables. We have defined the Liquidity of banks as a dependent variable, while the Profitability of banks, Non-performing loans, Capital Adequacy, the Interest rate on loans and Economic growth rate have been defined as independent variables of the study. The regression model was used to test the significance of these variables on banks' liquidity.

\subsection{Econometric model specification}

Based on the purpose of the paper, econometric model was built. To estimate the regression coefficients we will use the Ordinary Least Squares Method (OLS):

$Y_{i}=\beta_{0}+\beta_{1} X_{1}+\beta_{2} X_{2}+\ldots+\beta_{n} X_{n}+u_{i}$ 
$\Sigma \mathbf{u i}^{2}=\Sigma\left(\mathbf{Y i}-\beta_{0}-\beta_{1} \mathbf{X}_{1}+\ldots+\beta_{n} \mathbf{X}_{n}\right)^{2}=\min$

Based on the results of previous studies, it was found that there is difficulty in determining the factors influencing the Liquidity of banks. We have identified 5 independent variables or factors that we think to be the main factors influencing the liquidity of banks.

Multiple regression is used to construct model where $\mathrm{Y}$ appears as a function of independent variables. Our regression model includes the following variables:

$\mathrm{Y}=\mathrm{f}(\mathrm{X} 1, \mathrm{X} 2, \ldots, \mathrm{Xn})+\varepsilon$, in our case: $\mathrm{Y}=$ Liquidity $=\mathrm{f}(\mathrm{ROA}, \mathrm{NPLR}, \mathrm{CAR}, \mathrm{IRR}$, GGDP)

Based on the selected variables, the econometric model is presented in the following form:

$\mathbf{Y}\left(\mathbf{L q R}_{\mathrm{t}}\right)=\beta_{0}+\beta_{1} \mathbf{R O A}_{\mathrm{t}}+\beta_{2} \mathrm{NPLR}_{\mathrm{t}}+\beta_{3} \mathrm{CAR}_{\mathrm{t}}+\beta_{4} \mathrm{IRR}_{\mathrm{t}}+\beta 5 \mathrm{GGDPt}+\varepsilon_{\mathrm{t}}$

Where:

$\mathrm{Y}=$ Liquidity ratio $(\mathrm{LQR})$;

$\mathrm{X} 1$ = Return on assets (ROA), (Bank profitability);

$\mathrm{X} 2=$ Non - performing loans ratio (NPLR);

X3 = Capital Adequacy ratio (CAR);

$\mathrm{X} 4$ = Interest rate in lending ratio (IRR);

X5 = GDP Growth Rate (GGDP); (Annual \%)

All in period $t(t=$ period $2010-2019$, analyzed on a quarterly basis $)$

$\beta_{\mathrm{o}}=$ represent a constant,

$\beta_{1}$ to $\beta_{5}$ are coefficients (regression coefficient for variables which are been taken in the study);

$\varepsilon_{\mathrm{i}}=$ Error term, which includes the effect of variables that are not included in model;

Hypotheses:

1. Banks' profitability ( $\mathrm{RO} A$ ) has an important impact on the level of the banks' liquidity.

2. Non-performing loans (NPL) have an important impact on the level of the banks' liquidity.

3. Capital adequacy has an important impact on the level of the banks' liquidity.

4. The interest rate on loans has an important impact on the level of the banks' liquidity.

5. GDP growth has an important impact on the level of the banks' liquidity.

Ho: $\beta_{1}=0, \beta_{2}=0, \ldots, \beta_{5}=0$

H1: $\beta_{1} \neq 0, \beta_{2} \neq 0, \ldots, \beta_{5} \neq 0$

\subsection{Definition of variables}

Liquidity (LQ). Liquidity is defined as the bank's ability to pay its obligations on time without incurring any losses. It is considered as a very important factor for the success of banks. Bank liquidity is determined according to several reports. To determine liquidity, we have used the liquid assets to short-term assets ratio, which ratio shows the overall liquidity position of the bank.

Bank Profitability (ROA). Many studies present the profitability of banks as an important factor that positively affects the banks' liquidity (Lartey et. Al., 2013; Singh and Sharma, 2016; Vodova, 2013). While, there are other studies showing that high profitability brings to lower holding of liquid assets. A study conducted in Central America by Delechat et. al. (2012), considers the profitability of banks as a factor negatively connected to liquidity.

Non-performing loans (NPLs). A loan is considered non-performing when interest and principal payments have not been repaid in more than 90 days. According to Kumar and Tripathu (2012), NPL create problems in banks' sheet and negatively affect the income of 
banks as a result of the provision for loan losses. NPLs are the main cause of liquidity risk, which will send banks in the absence of funds to carry out their operations. Liquidity risk is the result of credit risk, which is the impossibility of borrowers to pay their obligations. Therefore, there is expected to be a negative correlation among non-performing loans and banking sector liquidity.

Capital Adequacy (CAR). Capital adequacy refers to the share capital available to support the bank's business. The amount of this capital measured by the ratio of net capital to total assets enables the bank to absorb any sudden shocks that can suffer. In cases where the bank loses its solvency, this capital is used to meet obligations to customers. According to Diep and Nguyen (2017), Capital Adequacy Ratio (CAR) has a positive and important relationship with the liquidity of commercial banks, viz. a bank with a higher CAR tends to have better liquidity.

Interest Rates on loans (IR). We have set the interest rate as an important indicator of monetary policy. The interest rate is considered as an important factor affecting banking activities. If the interest rate raises, the demand for credit falls which means a decrease in illiquid assets, but if there is an increase in interest rates on deposits the creation of liquidity by liabilities will increase. Thus, according to Berger et. al., (2017), if the impact on the liabilities side will increase more than the impact on the assets side, liquidity will increase and vice versa.

GDP Growth Rate (GGDP). GDP Growth Rate is a financial indicator of the health of a country's economy. The previous literature has shown mixed results regarding the impact of GDP Growth Rate on liquidity of banks. A positive relationship among GDP Growth Rate and banks' liquidity was given by the study conducted in 2008 by the authors Bunda and Desquilbet, while a later study by Chen and Phuong (2014) gives this relationship as negative.

Table 1. Study variables

\begin{tabular}{|l|l|l|}
\hline Variable & Description & Measuring \\
\hline LiqR & Liquidity ratio & Liquid assets/ short-term liabilities \\
\hline ROA & Return on assets ratio & Net income/ total assets \\
\hline NPLR & Non - performing loans ratio & Bad loans/ total loans \\
\hline CAR & Capital adequacy ratio & Share capital/ Total assets \\
\hline IRR & Interest rate ratio & Interest rate on lending (\%) \\
\hline GGDP & GDP Growth Rate & Annual growth rate of GDP (\%) \\
\hline
\end{tabular}

Source: Table created by the author

\section{Results of the Study}

The results obtained through the regression model give the impact of the variables taken in the study on the liquidity of commercial banks in Kosovo for the period 2012 2019. Data were analyzed for each quarter and processed through the statistical program SPSS 23.

\subsection{Descriptive statistics}

Descriptive statistics provide a summary of the variables obtained in the study. 
The table gives the minimum, maximum, average and standard deviation values for all variables included in the study, such as Bank Liquidity, Profitability, Non-performing Loans, Capital Adequacy ratio, Loan Interest Rate and Economic Growth.

Table 2. Descriptive statistics of the variablles (Author calculation)

\begin{tabular}{|l|c|c|c|c|c|}
\hline \multicolumn{6}{|c|}{ Descriptive Statistics } \\
\hline & $\mathrm{N}$ & Minimum & Maximum & Mean & Std. Deviation \\
\hline LQR & 32 & 31.30 & 45.30 & 39.2750 & $\mathbf{4 . 1 3 5 5 3}$ \\
\hline ROA & 32 & .82 & 3.00 & 1.9513 & $\mathbf{. 7 3 8 6 1}$ \\
\hline NPLR & 32 & 2.00 & 8.70 & 5.6191 & $\mathbf{2 . 3 1 0 8 9}$ \\
\hline CAR & 32 & 14.20 & 19.70 & 17.4500 & $\mathbf{1 . 1 6 1 4 8}$ \\
\hline IRR & 32 & 6.10 & 13.90 & 8.9531 & $\mathbf{2 . 7 2 4 0 8}$ \\
\hline GGDP & 32 & 1.60 & 4.90 & 3.6528 & $\mathbf{. 7 6 1 0 4}$ \\
\hline N & $\mathbf{3 2}$ & \multicolumn{7}{|l|}{} \\
\hline
\end{tabular}

Source: Calculated by author

\subsection{Test of multicollinearity}

The multicollinearity test is used to look at the relationship between independent variables. If the high value of multicollinearity between independent variables is observed, then their impact on the dependent variable is not significant. One method to assess multicollinearity is the Variance Inflation Factor (VIF). We use the VIF test to derive results on the variables link.

Table 3, gives us the values of the VIF test. From there it can be seen that the VIF for all independent variables is minor than 10 which shows that we do not face the problem of multicollinearity.

VIF $=1 /$ Tolerance

Table 3. VIF and tolerance for independent variables

Source: Calculated by author

\begin{tabular}{|l|c|c|}
\hline \multirow{2}{*}{ ROA } & \multicolumn{2}{|c|}{ Collinearity statistics } \\
\cline { 2 - 3 } & Tolerance & VIF \\
\hline NPLR & 0.201 & 4.968 \\
\hline CAR & 0.239 & 4.179 \\
\hline IRR & 0.437 & 2.113 \\
\hline GGDP & 0.110 & 9.067 \\
\hline
\end{tabular}

\subsection{The Results of the Econometric Model}

The following table summarizes the regression model. The value of $\mathrm{R}$ Square is 0.723 which means that $72.3 \%$ of the change in the liquidity of banks depends on the variables taken in the study (ROA, NPL, CAR, IR, and GGDP) while $27.7 \%$ of this change depends on the variables which have not been taken into study that may have an impact on liquidity (ui). 
Table 4. Model summary

\begin{tabular}{|c|c|c|c|c|}
\hline \multicolumn{4}{|c|}{ Model Summary } \\
\hline Model & R & R Square & Adjusted R Square & Std. Error of the Estimate \\
\hline 1 & $\mathbf{. 8 5 1}^{\text {a }}$ &. $\mathbf{7 2 3}$ & .670 & 2.37490 \\
\hline
\end{tabular}

Source: Calculated by author

The results presented in Table 5 show the importance of independent variables in the liquidity of commercial banks.

Table 5. Coefficients of the independent variables of model

\begin{tabular}{|c|c|c|c|c|c|c|}
\hline \multicolumn{7}{|c|}{ Coefficients } \\
\hline & \multirow{2}{*}{ Model } & \multicolumn{2}{|c|}{ Unstandardized Coefficients } & \multirow{2}{*}{$\frac{\text { Standardized Coefficients }}{\text { Beta }}$} & \multirow{2}{*}{$\mathrm{t}$} & \multirow{2}{*}{ Sig. } \\
\hline & & $\mathrm{B}$ & Std. Error & & & \\
\hline \multirow{6}{*}{1} & (Constant) & 21.617 & 10.615 & & 2.036 & .052 \\
\hline & ROA & -1.403 & 1.287 & -.251 & -1.090 & .286 \\
\hline & NPLR & 1.878 & .377 & 1.049 & 4.976 & .000 \\
\hline & CAR & 1.368 & .534 & .384 & 2.564 & .016 \\
\hline & IRR & -1.407 & .472 & -.927 & -2.983 & .006 \\
\hline & GGDP & -.394 & .750 & -.073 & -.525 & .604 \\
\hline
\end{tabular}

a. Dependent Variable: LiQR

Source: Calculated by author

The final econometric model identified to assess the liquidity of commercial banks is presented in the following form:

$\mathbf{L Q R}_{\mathrm{t}}=21.617-1.403 \mathbf{R O A}_{\mathrm{t}}+1.878 \mathrm{NPLR}_{\mathrm{t}}+1.368 \mathrm{CAR}_{\mathrm{t}}-1.407 \mathrm{IRR}_{\mathrm{t}}-\mathbf{0 . 3 9 4 G G D \mathrm { P } _ { \mathrm { t } }}$ The profitability of banks does not have an important impact on the liquidity of commercial banks in Kosovo. Our study used ROA as a measure of profitability, which indicator did not have an important effect on the liquidity of Kosovo commercial banks, based on the data of study.

Non-performing loans have a significant positive effect on the liquidity of commercial banks in Kosovo, which is contrary to the literature reviewed previously. According to this we can say that the increase of non-performing loans will increase the liquidity of banks and vice versa.

Capital adequacy has a positive and important effect on the liquidity of commercial banks in Kosovo. Keeping a portion of the capital as a reserve is useful in situations where banks are faced with surprises, such as large withdrawals from depositors. Increasing this ratio increases the liquidity of banks and makes banks more confident in meeting their obligations, which is consistent with most of the literature reviewed.

The interest rate on loans has a negative and important effect on the liquidity of commercial banks in Kosovo. Interest rates on loans continued to decline as a result of the improvement of the overall business environment. The decline in interest rates on loans is the main factor that causes the growth of credit applications and as a result of this will increase liquidity of the banking sector. Such a negative ratio between banks' interest rates and bank liquidity has been seen in most of the literature. 
GDP Growth Rate has a non-important negative effect on the liquidity of commercial banks in Kosovo. Usually based on previous studies we can say that economic growth is an important factor in increasing the liquidity of commercial banks but also economic wellbeing as a whole. However, in our study based on the processed data, GDP does not have a significant impact on banks' liquidity.

Table 5. Statistical indicators of study hypotheses (Calculated by author)

\begin{tabular}{|l|c|c|c|}
\hline Hypothesis: & $\mathrm{p}$ - value & Decision & Impact \\
\hline $\begin{array}{l}\text { 1. Banks' profitability (ROA) has an important impact on the } \\
\text { level of the banks' liquidity. }\end{array}$ & $\mathbf{0 . 2 8 6}$ & Rejected & \\
\hline $\begin{array}{l}\text { 2. Non-performing loans (NPL) have an important impact } \\
\text { on the level of the banks' liquidity. }\end{array}$ & $\mathbf{0 . 0 0 0}$ & Accepted & Positive \\
\hline $\begin{array}{l}\text { 3. Capital adequacy has an important impact on the level of } \\
\text { the banks' liquidity. }\end{array}$ & $\mathbf{0 . 0 1 6}$ & Accepted & Positive \\
\hline $\begin{array}{l}\text { 4. The interest rate on loans has an important impact on the } \\
\text { level of the banks' liquidity. }\end{array}$ & $\mathbf{0 . 0 0 6}$ & Accepted & Negative \\
\hline $\begin{array}{l}\text { 5. GDP growth has an important impact on the level of the } \\
\text { banks' liquidity. }\end{array}$ & $\mathbf{0 . 6 0 4}$ & Rejected & \\
\hline
\end{tabular}

As a rule hypotheses are accepted if the value of $\mathrm{p}$ is less than 0.05 . The first and fifth hypotheses are rejected for the fact that the values of $\mathrm{p}$ are not within the accepted values. From this, we conclude that the profitability of banks (measured by ROA) and GDP do not have an important effect on the banks' liquidity in Kosovo, more exactly they did not have an impact during the study period. While from the data of the coefficient table according to the value of the coefficients and the value of the significance, it can be seen that NPL, CAR and IR in credit have an important impact on the banks' liquidity in Kosovo. NPLs have a positive effect on bank liquidity, which means that with the increase in non-performing loans, bank liquidity increases, which is contrary to part of the studied literature. CAR has a significant positive effect on increasing the liquidity of banks, due to the fact that with the increase of available capital the bank is in a better position of liquidity by meeting unexpected liabilities or losses. The interest rate on loans has turned out to be negatively related to the banks liquidity, a relationship that is statistically significant.

\section{Conclusion}

Commercial banks require special attention in the study of their financial elements and even more so when it comes to liquidity. The availability of data provided by commercial banks has enabled the realization of this topic, ie to see the factors that affect the liquidity of commercial banks.

The paper analyzed the effects of several selected factors (ROA, Non-performing loans, Capital adequacy, Interest rate on loans and GDP growth rate) on the liquidity of Kosovo commercial banks during the period 2012-2019.

According to the data and analysis carried out within the study, we can come to the following conclusions:

ROA is negatively related to the liquidity of commercial banks in Kosovo. This relationship comes from the fact that the increase in this indicator implies a decrease in 
liquidity as a result of increased investment in assets. This impact was insignificant for the study period.

NPLR has a positive impact on the liquidity of commercial banks in Kosovo. In recent years, non-performing loans have been steadily declining. As a result, commercial banks have not been forced to hold many liquid assets. In contrast, when the non-performing loan ratio was high, banks were prudent in investing and holding liquid funds.

CAR is positively related to the liquidity of commercial banks in Kosovo, due to the fact that the banking system in Kosovo is well-capitalized and exceeds the minimum regulatory requirements. And the high ratio of banks' capital constantly creates a positive signal for the public by attracting more deposits.

IR in loans has been characterized by a steady decline, thus contributing to the increase in lending by banks and consequently the increase in liquid assets. As a result, the relationship between the interest rate on loans and the liquidity of banks in Kosovo has been negative during the period of the study.

GGDP as in many other studies in the banking sector in Kosovo is negatively related to bank liquidity. When the economy is characterized by growth, banks make investments to increase profits, thus reducing liquid assets. However, in the commercial banks in the country, this impact has proved insignificant due to very small fluctuations as a result of macroeconomic developments in the country.

There are not many similar studies in Kosovo that have addressed this topic, so the findings of this paper will be valuable to stakeholders in the banking industry and also provide a useful basis on which similar studies can be conducted.

\section{References}

Ahmed, N. et. al. (2011). Liquidity risk and Islamic banks: Evidence from Pakistan. Interdisciplinary Journal of Research in Business, 1(9), 99-102.

Al-Homaidi et.al., (2019) The determinants of liquidity of Indian listed commercial banks: A panel data approach, Cogent Economics \& Finance.

Berger, A., \& Bouman, C. (2019). Bank liquidity creation. Review of Financial Studies, Vol.22, Issue 9 (3779 3873).

Berger, A., \& Bourman, C. (2017). Bank liquidity creation, monetary policy and financial crisis. Journal of Financial Stability, 30, 139- 155.

Bharti, U. \& Singh, S. (2014). Liquidity and Profitability Analysis of Commercial Banks in India - A Comparative Study, Global Journal of Enterprise Information System, Vol.6, Issue 4 (24 - 28).

Bhati, Shyam S. et.al. (2019). Factors affecting the liquidity of commercial banks in India: a longitudinal analysis. Faculty of Business - Papers (Archive). 1646.

BIS (2008) Principles for sound liquidity risk management and supervision. Basel Bank for International Settlements.

Bunda, I \&Desquilbet, J 2008, 'The bank liquidity smile across exchange rate regimes of 36 emerging countries commercial banks', International Economic Journal, Vol. 22, No. 3, pp. 361-386.

Chen, I. J., \& Phuong, N. L. (2014). The determinants of bank liquidity buffer. Retrieved from https://mediacast.blob.core.ëindoës.net/production/Faculty/StoëeConf/submissions/sëfa2014_s ubmission_9.pdf.

Delechat, C., Henao, C., Muthoora, P., \& Vtyurina, S. (2012). The determinants of banks' liquidity buffers in Central America. No.12-301. USA: International Monetary Fund.

Devinaga, R. (2010). Theoretical Framework of Profitability as Applied to Commercial Banks in Malaysia. European Journal of Economics, Finance and Administrative Sciences 23, $149-160$. 
Diamond, D. W., \& Rajan, R. G. (2001). Banks, short-term debt and financial crises: Theory, policy implications and applications. Carnegie-Rochester Conference Series on Public Policy, 54(1), 3771.

Diep \& Nguyen (2017). Determinants of Liquidity of Banks in Vietnam. International Journal of Scientific Study, Vol. 5, Issue 6.

Horváth, R., Seidler, J., \& Weill, L. (2014).Bank capital and liquidity creation: Granger causality evidence. Journal of Financial Services Research, 45(3), 341-361.

Khoury, R. (2018). The Impact of Bank Liquidity on the Lebanese Banks' Risk Taking Behavior, Journal of International Business and Economics, Vol.6. No.1 (12 - 28).

Kumar, A., Tripathi, A. 2012. NPAs management in Indian banking - policy implications. IMS Manthan, 7(2), $10-17$.

Lartey, V.C. et. al. (2013). The Relationship betëeen Liquidity and Profitability of Listed Banks in Ghana. International Journal of Business and Social Science, Vol.4. No.3 (48 - 56).

Mehdi, F \& Abderrasoul, L. (2014). Liquidity Determinants of Maroccan Banking Industry, International Journal of Finance and Economics, Issue 118 (102 - 112).

Morina, D. (2020). Determinants of credit risk in commercial banks of Kosovo. International Journal of Economics and Business Administration, 8(2), 179-190.

Mousa, M. (2015). The Determinants of Bank Liquidity: Case of Tunisia, International Journal of Economics and Financial Issues, Vol.5, No.1 (249 - 259).

Sheefeni \& Nyambe (2016). Macroeconomic determinants of commercial Bank's liquidity in Namibia. European Journal of Business, Economics and Accountancy. Vol.4, No.5 (19 - 30).

Shershneva, E.G, et.al. (2020). Econometric Modeling of the Bank's Short - Term Liquidity Dynamics Based on Multi - Factor Regression. Jounral of Applied Economic Research, Vol.19, No.1. (79 - 96).

Singh, A. \& Sharma, A.K. (2016). An empirical analysis of macroeconomic and bank - specific factors affecting liquidity of Indian banks. Future Business Journal $2(40-53)$.

Vodova P. (2011). Liquidity of Czech Commercial Banks and its Determinants. International Journal Of Mathematical Models And Methods In Applied Sciences, Vol.5, Issue 6 (1060 - 1067).

Vodová P. (2013). Determinants of commercial bank liquidity in Hungary. Financial Internet Quartely, 9(3), $(180-188)$.

Wojcik - Mazur, A., \& Szajt, M. (2015). Determinants of Liquidity Risk in Commercial Banks in the European Union. Argumenta Oeconomica, 35, (25 - 47). 